\begin{tabular}{|c|c|} 
MAGYAR GERONTOLÓGIA \\
13. ÉVFOLYAM 40. SZÁM \\
$\qquad \begin{array}{l}\text { On-line verzió: ISSN 2062-3690 } \\
\text { www.https://ojs.lib.unideb.hu/gerontologia }\end{array}$ \\
\hline
\end{tabular}

\title{
-TUDOMÁNYNÉPSZERÜSÍTŐ-
}

\section{BÖLCS ÖREGEDÉS AZ ÉLETÚT ALKONYÁN}

\section{Homor Tivadar}

Kulcsszavak: gerontológiai dimenziók, időskori létállapot, öregség arcai, bölcs életfilozófia mentális gondozás, életútelemzések

\begin{abstract}
Absztrakt
A tanulmány rávilágít arra, hogy a megtett életút minősége, milyen lenyomatot képez időskori énünkben. Az öregedés folyamatának komplex bemutatásával árnyaltabb diagnózist lehet felállítani az időskor sokarcúságáról, ezáltal hatékonyabb prevenciós-, és gondozó tevékenységet lehet folytatni. A tanulmányban vázolt pozitív életfilozófia alkotóelemeinek megismerése és gyakorlatban való alkalmazása, hozzájárul az időskori mentális egyensúly fenntartásához.
\end{abstract}

Gyakorlati relevanciák: A kutatás eredményei elsősorban gondozóintézetekben idősotthonokban és nyugdíjas klubokban hasznosíthatók. Hatékonyan segíthetik az idős emberek testi - lelki - szellemi gondozását és problémás élethelyzetük elfogadását. A tanulmány felhasználható az alap és középfokú andragógiai képzéseken és szaktanfolyamokon (szociális munkás, szakápoló, terapeuta)

Keywords: gerontological dimensions, faces of old age, mental care, life path analyzes 


\begin{abstract}
The study highlights what impression the quality of our life history has on our elderly ourselves. With this complex presentation of the aging process, a more nuanced diagnosis could be made about the versatility of ageing, thus more effective prevention and care programs could be carried out. The recognition and application of the positive philosophy of life outlined in the study contribute to maintaining good mental health of the elderly.
\end{abstract}

Practical relevance. The results of the research can be primarily utilzed in care institutions, nursing homes and retirement clubs. It can effectively help the physical, spiritual and mental care of elderly people and help them accept their problematic life situation. The study might be utilized in practice on elementary and intermediate andragogy trainings and on vocational courses (social worker, specialist nurse, therapist).

\title{
A tanulmány célja
}

A test - lélek - szellem dimenziójából mutatja be az öregedés folyamatát. Irodalmi, müvészeti, filozófiai, vallási és erkölcsi példákon keresztül érzékelteti időkorunk sokarcúságát. Rávilágít arra, hogy öregkori mentális állapotunk alakulását, milyen mértékben befolyásolja életutunk minősége. Mi az oka annak, hogy az elmúlás határán egyes emberek bölcsebben mások csak öregebben lépik át az időskor küszöbét. Diagnosztizálja a korosztály gondjait és problémáit. Életvezetési alternatívákat javasol a kiegyensúlyozott lelkiállapot fenntartásához. Időskori életérzés statisztikák tükrében, eltérő életutakat és magatartásformákat elemez.

Módszerek: személyes interjú, életút - elemzés, szakirodalom tanulmányozása 


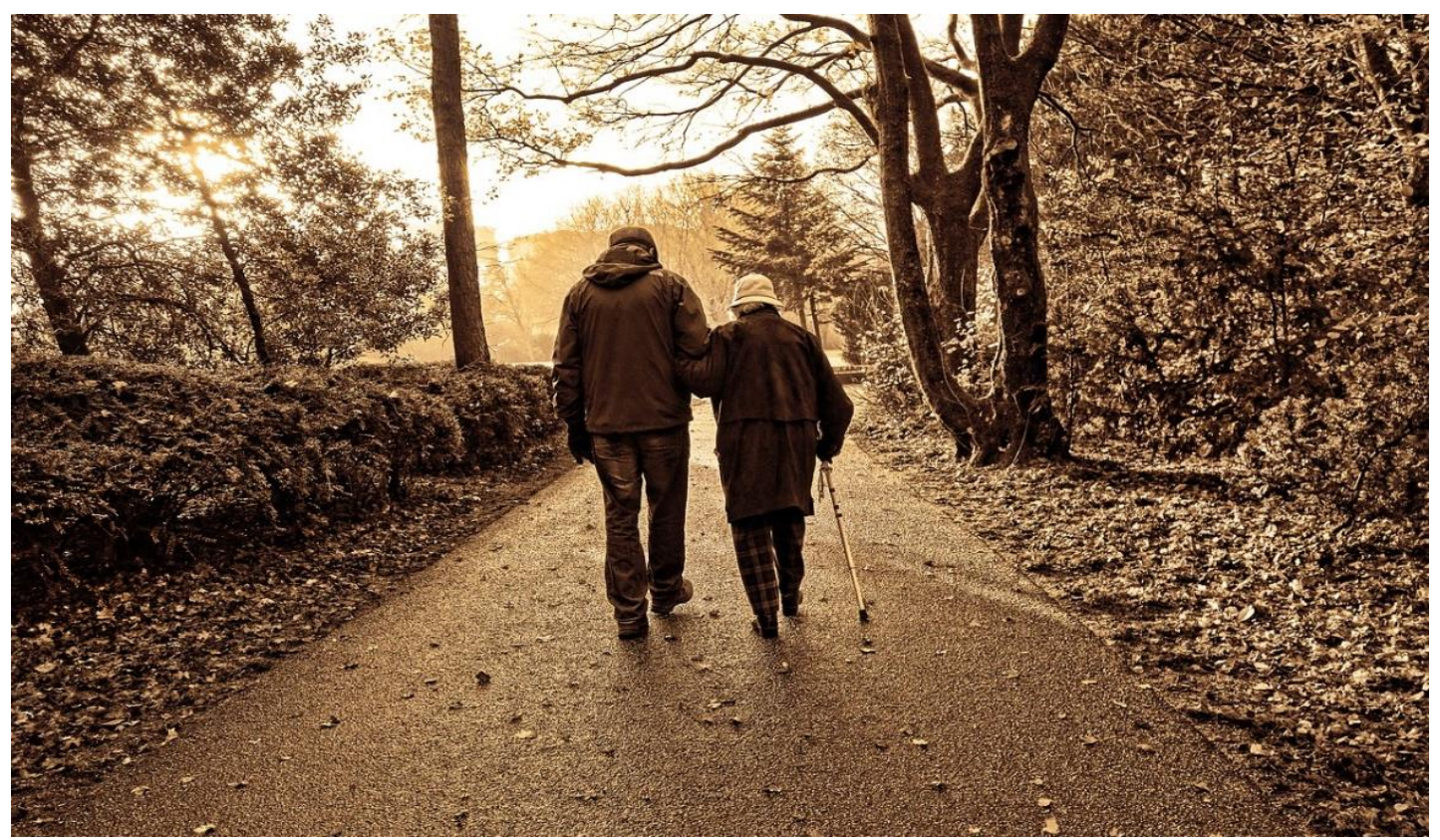

1. Ábra: Idős házaspár. Séta. forrás:

https://pixabay.com/hu/images/search/id\%C5\%91s\%20p\%C3\%A1r/

Földi létünk legnagyobb problémája az idő, és az elmúlás. Megszülettünk, elindultunk lezáratlan életünk ordas ösvényén, úttalan utakon gyakran eltévedtünk és cél nélkül bolyongtunk. Távoli egzotikus tájakra vágytunk, mely nem lett otthonunk. Hajtott bennünket vad ösztönös éhség, nyugtalanság, vak reménység. Kínba fúlt mámorunkért, a puszta semmiért kockáztattuk a biztos meglevőt. Zaklatott életünk kaotikus világában vágy vezérelt képzeletünk hamis fantomjait követve, lázasan hajszoltuk a sikert, és az érvényesülést. Balgán reméltük, hogy valami értelmes nyomot hagyunk magunk után a múló időben. E talmi értékekért szinte mindent feláldoztunk: barátság, szerelem, család, egészség. Aztán egy hideg őszi reggelen arra ébredtünk, hogy „, a semmi ágán ül szívünk”, a kegyetlen idő észrevétlenül - ajtót sem csapva elrabolta fiatalságunk. Egyre fogynak napjaink, lassan lepereg előttünk eltékozolt életünk. Ha ködbe burkolódznak a fák, furcsa árnyak táncolnak a lelkünkben. Mint falevél a novemberi szélben nyugtalan lelkünk havas mezőkön kóborol, halk lépteink az örök hajlék felé visznek. A némaság béna perceiben megérint bennünket az elmúlás az élet végességének gyötrő, fojtogató élménye. Elképzeljük, milyen az a hely, ,hova senkise jut soha kétszer: a legmesszebb a legközelebb". ${ }^{2}$ Az őszi ködben felsejlik Kháron ${ }^{3}$ ladikja, mely ránk vár, hogy átvigyen bennünket az innenső partról a túlsó partra, Hádész ${ }^{4}$ birodalmába. Ha ilyen gondolatok kavarognak lelkünkben, elérkeztünk életünk utolsó szakaszához az öregkorhoz. 


\section{A hosszú élet és a halhatatlanság titkát keresve}

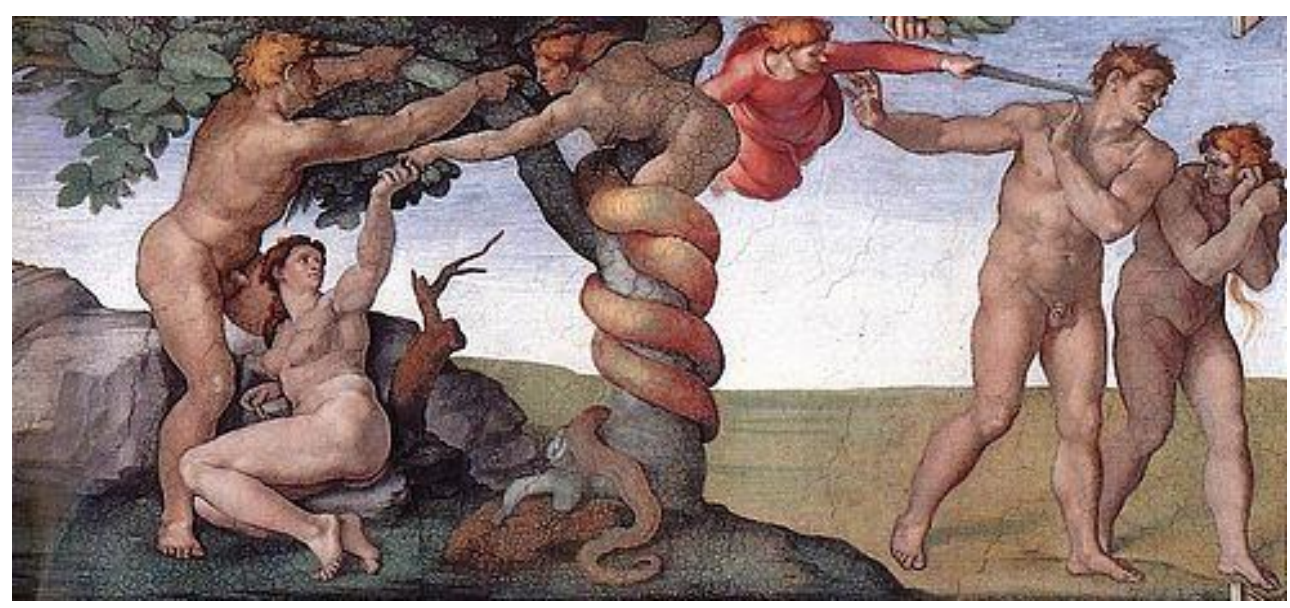

2. Ábra: Kiüzetés a paradicsomból. forrás:

https://hu.wikipedia.org/wiki/Az_ember_buk\%C3\%A1sa

Mióta ember él a földön szüntelen keresi az örök lét titkát. Az ószövetség teremtésmítoszából tudjuk, hogy az édenkert kapuja örökre bezárult az ember előtt, amikor Isten, Ádámot és Évát bűnük miatt kiüzte a paradicsomból. „Átkozott legyen a föld miattad, fáradságos munkával élj belöle életednek minden napjaiban. Tövist és bogáncskórót teremjen neked; s egyed a föld növényeit. Arcod veritékével egyed a te kenyeredet, mígnem visszatérsz a földbe, mert abból vétettél: mert por vagy te, és ismét porrá leszel" ${ }^{\prime 5}$. Édentől Keletre kezdetét vette az emberiség kínokkal és szenvedéssel teli, gyötrelmes élete. A bünbeesés óta, a földi élet gyilkos harcmezővé vált, a halál az élők büntetése lett. Gilgames ${ }^{6}$, a mondabéli sumér király és a középkorban élt alkimisták is a csodálatos életelixírt keresték, mindhiába. Reménytelen küldetésük kudarcra ítéltetett, be kellett érniük azzal a szomorú felismeréssel, hogy ami teremtetett elmúlik, semmi sem tart örökké. 


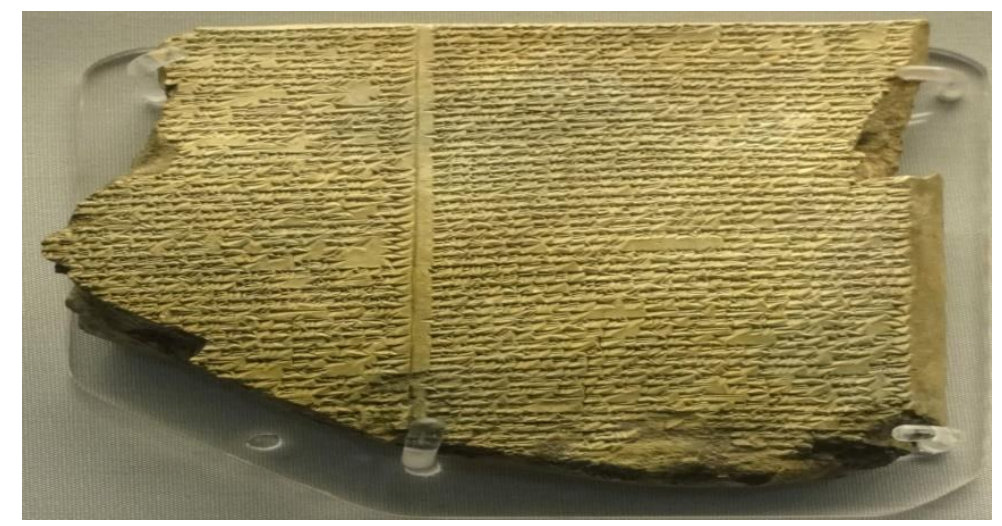

3. 3. Gilgames eposz-részlet. Sumér ékírásos agyagtábla. forrás:

https://upload.wikimedia.org/wikipedia/commons/b/bc/Library_of_Ashurbanipal_The_Flood

Napjaink genetikusai, a sejtek újra programozásával, gén-, nanotechnológiával kísérleteznek. Regeneratív orvoslással a betegségek kiküszöbölésére, az elmúlás és az öregedés kitolására törekednek (akár 150-200 évig is élhetünk) Végső cél: idegpályáink áthuzagolásával a testilelki fájdalom kiiktatása, a mentális harmónia, az örök boldogság, a hallhatatlanság, a megistenülés elérése. Optimista tudósok víziója szerint a 21. század második felében eljön a mesterséges intelligencia kora, ,,megkisérelhetjük legyőzni az öregedést, akár magát a halált is, belefoghatunk abba, hogy a Homo sapiensböl (értelmes emberböl) Homo deust (istenembert) csináljunk." " Nem tudhatjuk, hol húzódnak emberi kiteljesedésünk határai, aggasztónak tünnek azok a jóslatok, melyek szerint, fel kell készülnünk arra, hogy néhány évtized múlva félig emberek, félig robotok leszünk. A szingularitás ${ }^{8}$ korában az ember odáig merészkedik, hogy Istent csináljon magából, az a civilizációnk végét jelentheti.

\section{Az öregség arcai}
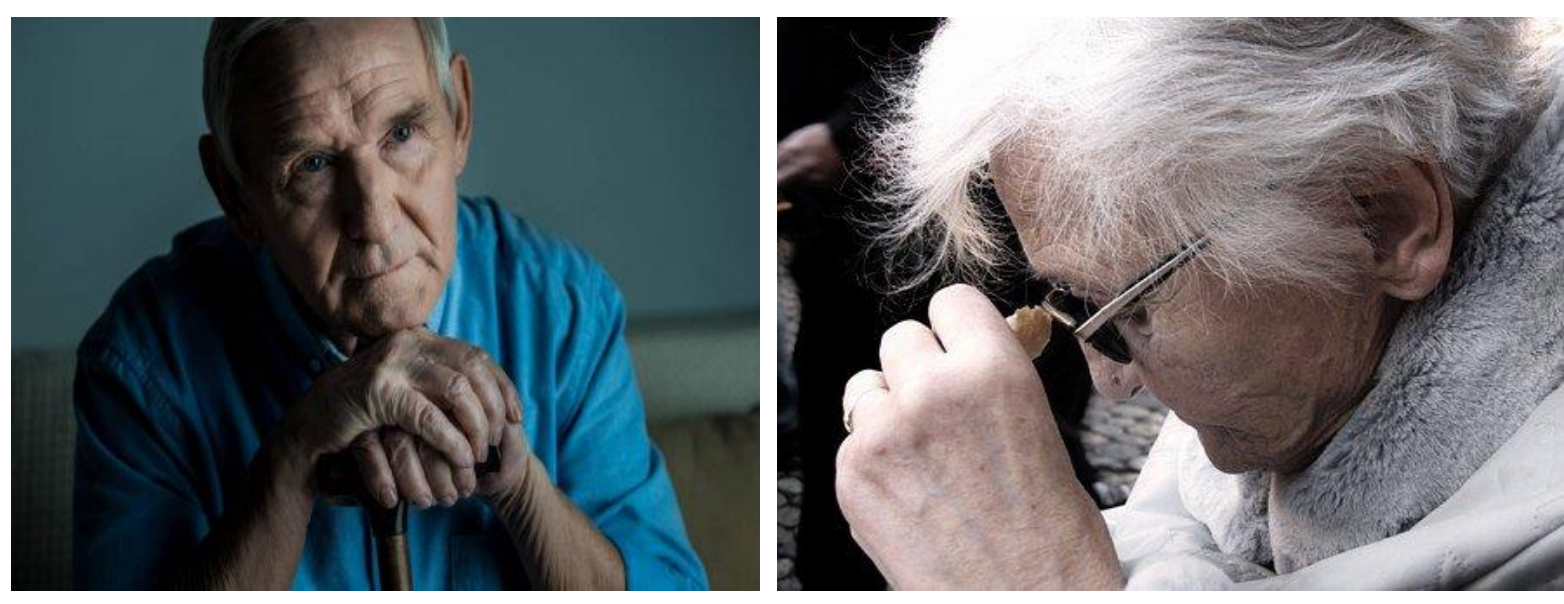

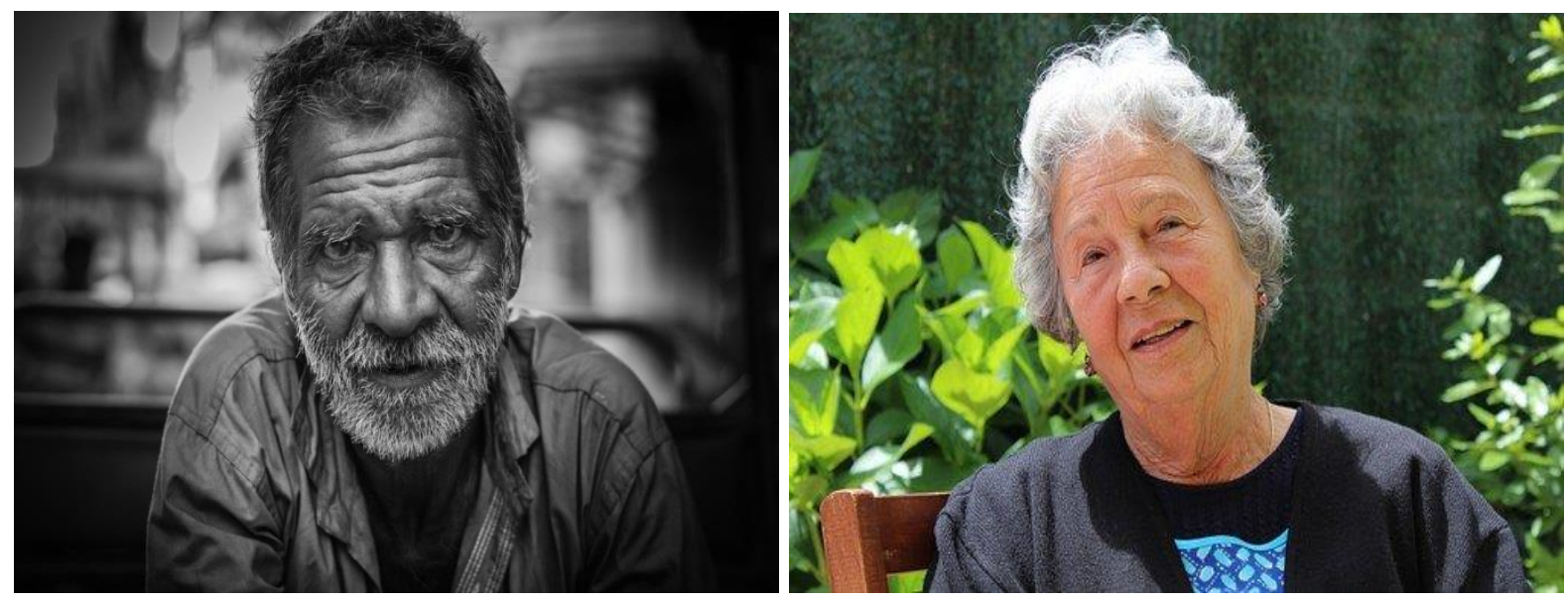

4. Ábra: Arcok. https://hu.depositphotos.com/stock-photos/id\%C5\%91s-emberek-st200.html

A gerontológia az öregedés tudományával foglalkozik. Az elmúlt évtizedekben ez a tudományterület felértékelődött, az orvostudomány fejlődésével egyre jobban kitolódik az idős kor. A fejlett országokban, komoly problémát jelent a népesség elöregedése, az idős emberek gondozása. Az öregedéssel elkezdődik, testi, lelki, és szellemi hanyatlásunk. Minden érzékszervünk romlik, egyre nehezebben tudunk alkalmazkodni gyorsan változó környezetünkhöz, ráadásul mentális egyensúlyunk is gyakran labilissá válik. Amikor sejtjeink nem osztódnak tovább kezdetét veszi az öregedés, beköszönt az ősz, a hulló falevelek évadja, belső óránk visszafordíthatatlanná válik. Testünkön és lelkünkön a könyörtelen idő mély nyomokat hagy, csontjainkig hatol a tél fagyos lehelete. Átgázolt rajtunk az élet, kétségbeesve keressük hervadó emlékké vált múltunk összetört tükörcserepeit. Céltalanul elherdált éveink után nehezen találunk vissza önmagunkhoz, gyakran hatalmas ür tátong a lelkünkben, magányosnak és istenverte vesztesnek érezzük magunkat. Álmatlan éjszakákon az agyvérzés, a szívinfarktus, a rák és a demencia rémképei gyötörnek bennünket. Egyre gyakrabban köszönt ránk rossz kedvünk tele. „Zordságod sok szép napot megöl. Egésznap dohogsz, mint egy roskatag malom, úgy kell neked vénséged elöl miért nem szöktél el fiatalon"9 . 


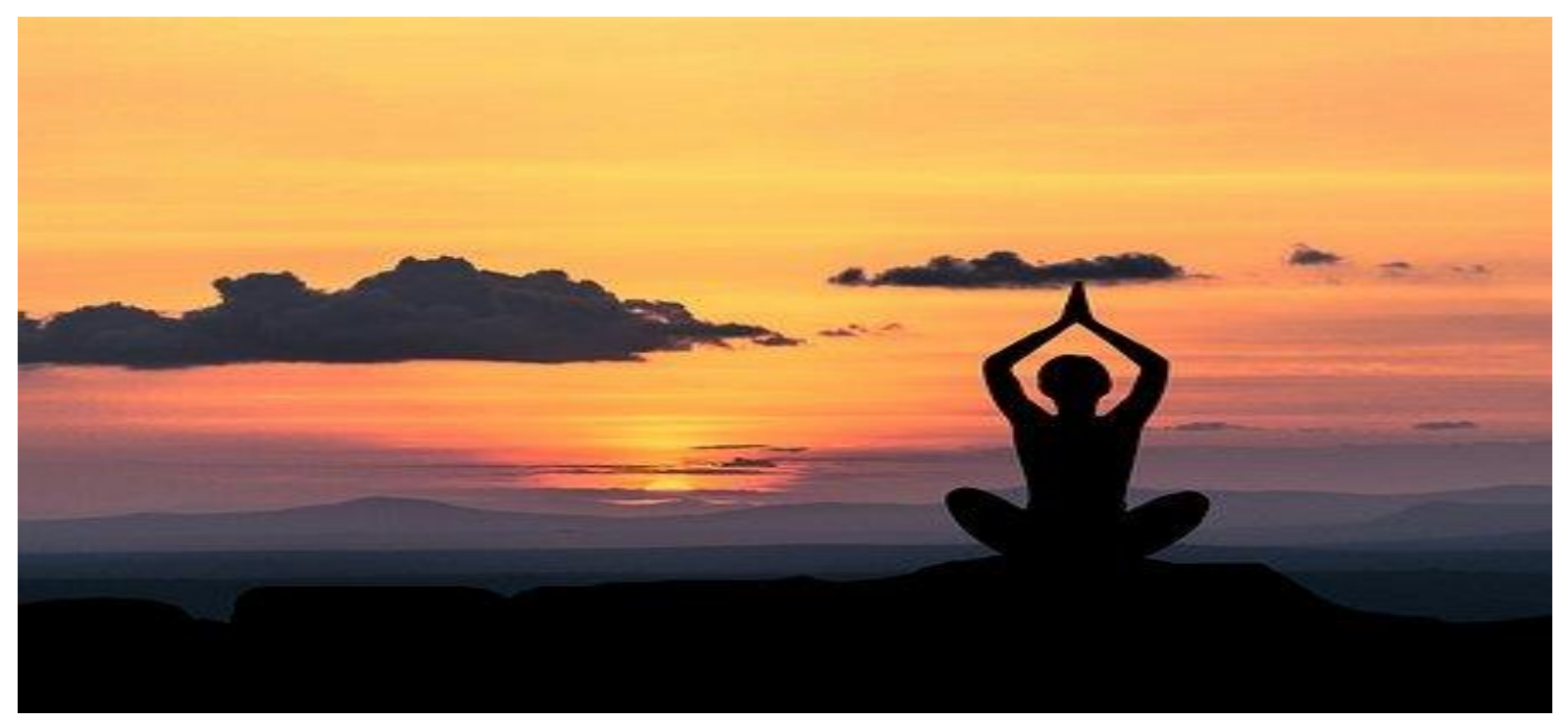

5. Ábra: Meditáció. https://pixabay.com/hu/images/search/b\%C3\%B6lcsess\%C3\%A9g/

Idős korban gyakran tesszük fel magunknak a kérdést, vajon tanultunk e életünk során hozott rossz döntéseinkből, hibáinkból, céltalan tévelygéseinkből, öncsaló nekirugaszkodásainkból? Bölcsebbek, vagy csak öregebbek lettünk? Önreflexiónkra adott válaszunk, sem egyértelmü, mert nincsen két egyforma idős ember, mindenki más és más életutat járt be. Úgy tartja a mondás: mindenkinek meg van a maga keresztje, kinek könnyebb, kinek nehezebb élet adatott. Az életút függvényében minden ember eltérő testi, lelki, szellemi állapotban jut el az idős kor küszöbéig. Következésképpen nagyon sok arca van öregkori létünknek. Aktuális mentális állapotunktól függ, hogy az adott időszakban bölcsebben: pozitív életfillozófiával (optimistán, derüsen, nyitottan, aktívan, hittel, elfogadással,) vagy csak öregebben (nyügösen frusztráltan, kínoktól gyötörve, dühösen, elkeseredetten, reményvesztetten, magányosan) éljük mindennapjainkat. 


\section{Öreg korunk gondjai és problémái}

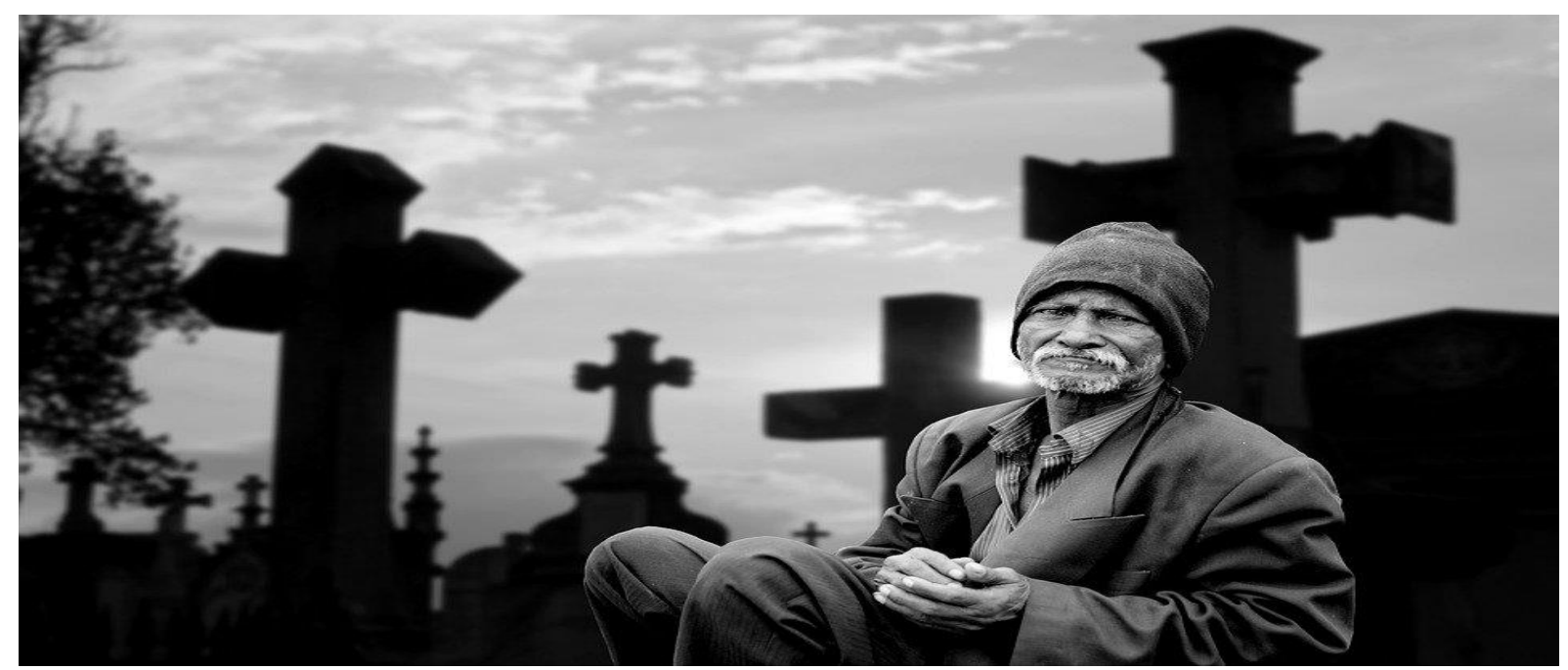

6. Ábra: Gyászmunka. https://pixabay.com/hu/photos/emberi-f\%C3\%A9rfi-gy\%C3\%A1szszomor\%C3\%BAs\%C3\%A1g-2829510/

Napjaink irreálisan felgyorsult világában az idős emberekkel való törődést nyügnek és tehernek érzi a civilizált társadalom. A fejlett nyugati országokban is, egyre nagyobb terhet és kihívást jelent az idősek növekvő aránya a fiatalabb korosztályokhoz képest. Kellően átgondolt stratégia hiányában, a kormányok képtelenek megfelelően kezelni a demográfiai pánikot ${ }^{10}$. Az országos, és helyi szociális ellátórendszerek, nyugdíjas szervezetek, klubok, gondozó intézetek nincsenek felkészülve a megnövekedett társadalmi elvárások kielégítésére. Az idős emberek problémáinak enyhítésére, az eddiginél lényegesen hatékonyabb financiális -, szakmai-, és mentális támogatásra lenne szükség. A digitális világ fiatal nemzedékének szent fétisei: a siker, a hírnév, a karrier és az egoizmus. Az individualizmusra épülő on - line világ nem, vagy alig illeszthető az idős ember személyiségébe, ezért a totális izoláció és széthullás zürzavara fenyegeti. Néhány év múlva az elöregedett korosztály számára is nélkülözhetetlen társadalmi, gazdasági, kulturális, egészségügyi, szabadidős és más közhasznú szolgáltatások döntőtöbbsége, csak digitális úton lesz elérhető/igénybe vehető. A hetven év feletti korosztály jelentős része képtelen eligazodni ebben a világban, idegenkedik tőle, vagy bizalmatlan vele szemben. Ez a ,, digitális szakadék" "11 súlyos mentális zavarokat idézhet elő személyiségükben. Növeli az idős emberek további problémáját, hogy a nyugdíjazáskor ki kerülnek a munka világából, közösségi, baráti kapcsolatai beszükülnek, vagy elhalnak, gyakran feleslegesnek és otthontalannak érzik magukat. Mindannyian ,,azért jöttünk a világra, hogy valahol otthon legyünk benne" ${ }^{\prime 2}$ Mentális otthonosság hiányában a külvilágtól teljesen elszigetelődnek, bezárkóznak, elmagányosodnak, a kiszolgáltatottság ördögi csapdájába kerülnek, mely 
személyiségük dezintegrációjához vezethet. A személyiség teljes leépülésekor az élet elveszti értelmét. Az öregkori problémakezelés az eddigieknél magasabb szintü törődést, odafigyelést és empátiát várna el a fiatalabb korosztályoktól a hozzátartozóktól és a regnáló kormányoktól egyaránt.

\section{Az életút hatása az öregkorra}

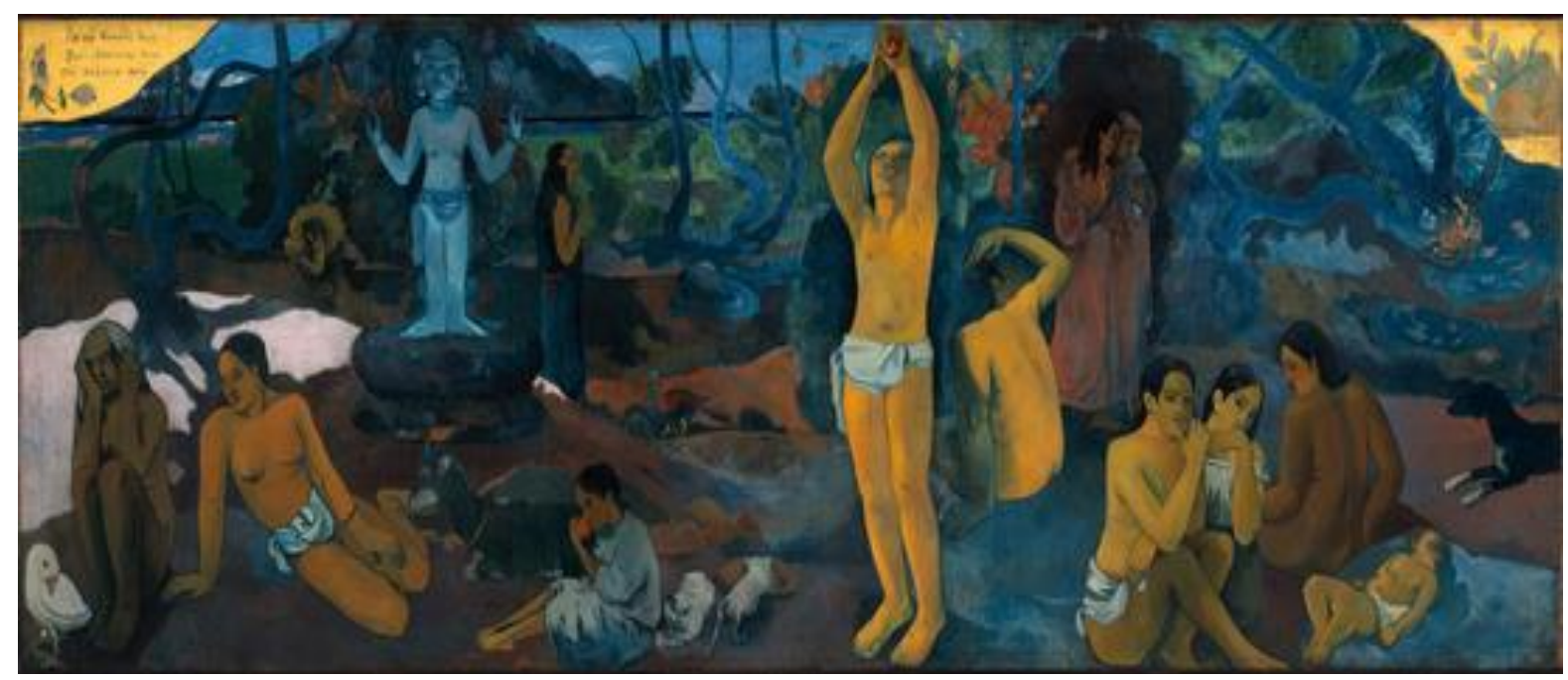

7. Ábra: Paul, Gauguin: Honnan jövünk, kik vagyunk, hová megyünk?

https://moly.hu/enciklopedia/paul-gauguin-honnan-jovunk-kik-vagyunk-hova-megyunk

Rögös életutunkat térben és időben csak egyszer van lehetőségünk végig járni, nincsen módunk ismétlésre, hibáink, botlásaink javítására. Életünk, megélt hétköznapok visszafordíthatatlan egymásutánisága, és különböző élethelyzetek kaotikus sokasága. Minden életszakaszunk az „,ismeretlenség bolygója, ”13 ez azt jelenti, hogy amikor belépünk egy adott életszakaszba nincsen tapasztalásunk arról, hogy milyen kihívások várnak ránk és ezekre a kihívásokra, milyen megküzdési stratégiákat tudunk kialakítani. Életünkben gyakran válaszút elé érkezünk néha több, máskor kevesebb lehetőség közül választhatunk, de csak egy úton indulhatunk el. „Erdön két út: mentem igen, arra amerre kevesen, és minden eldölt akkor ott" ${ }^{14}$ Jó és rossz döntéseinknek meg van a következménye, melyek elől nem térhetünk ki vállalnunk kell a felelősséget. Életünk során szerzett pozitív negatív tapasztalataink, sikereink, kudarcaink, mély nyomokat hagynak lelkünkben, befolyásolják életérzésünk minőségét és előrevetítik öregkorunk mentális állapotát. 


\section{Eltérő életutak, ambivalens életérzések és magatartásformák}

Ha visszatekintünk életutunkra, leltárt készítünk, ilyenkor számos önreflexiós kérdést teszünk fel magunknak. Honnan jöttünk? Kik vagyunk? Milyen a személyiségünk-, önismeretünk? Mi végre születtünk erre a furcsa világra? Mi a hozadéka önmegvalósítási törekvéseinknek? Volt e kellő hitünk, akaraterőnk vagy csak ide - oda sodort bennünket a szél? Ha ezekre a kérdésekre hiteles válaszokat adunk, rálátunk életünk minőségére. Személyiségünk, erkölcsi arculatunk, elsősorban alternatív életstratégiánk tükrében mutatkozik meg leginkább. Választásunk a bőség kosarából, többnyire neveltetésünktől, értékrendünktől és testi, lelki, szellemi adottságainktól függ leginkább. Fiatalon, - „, hunyt szemmel, bérceken futunk, s mindig csodára vágy szívünk, a legjobb amit nem tudunk, a legszebb amit nem hiszünk"15 - s abban bízunk, hogy öneröből képesek leszünk törekvéseinket és vágyainkat beteljesíteni. Választott értékvilágunkat követve reméljük, hogy lesznek életünknek olyan kivételes pillanatai, melyek a teljesség csúcsélményét és személyes kiteljesedésünket adják. E célok eléréséhez, úttalan utakon kell ösvényt taposni, mely legjobban szolgálja önmegvalósításunkat. A mai modern multikulturális társadalmakban zavarba ejtően sokféle életút - modell kínálkozik ${ }^{16}$ A lehetőségek plázájából, minden ember más és más választott célt követve (tudatosan vagy ösztönösen) véli megtalálni élete értelmét.

\section{Mit mutatnak az időskori életérzés statisztikák}

Nyugdíjas klubokban, idős otthonokban „Bölcs öregedés” címmel tartott prezentációim és interjúim során végzett (nem reprezentatív) méréseim szerint, az idős emberek 18\%-a ítélte sikeresnek életútját (több örömteli, boldog perc adatott nekem, mint fájdalom és szenvedés). A megkérdezettek $47 \%$ - a kudarcosnak értékelte élete hozadékát (túl sok volt a fájdalom, a csalódás és a sikertelenség). Ambivalensnek (kétarcúnak: egyszer lent, máskor fent) minősítette életét, $31 \%$. Nem adott egyértelmü választ 4\% A három leggyakrabban választott életútnak is számtalan árnyalata rajzolódott ki a felmérésből. A beszélgetésekből az is kiderült, hogy az idős emberek mentális energiáit az életút mindennapjainak gyötrelmei, csalódásai, kiúttalanságai és frusztrációi emésztették fel leginkább, melyeknek nem kívánt következménye időskorban a krónikus depresszió. E szorult élethelyzetben a reményvesztett lélek leggyakoribb menekülési útvonala a biokémiai boldogságkeresés (alkohol, drog, gyógyszerek, játékszenvedély, mértéktelen étkezés) A megkérdezett idős emberek döntő többsége által választott tipikus életutak (életérzések) föbb jellemzöi. 


\section{Sikeres életút/Izgalmas, kihívásokkal teli utazás}

A sikeres életutat bejárt emberek, létük megélését, titkokkal és kalandokkal teli izgalmas utazásként értékelik. Attitüdjeik, érzéseik, gondolataik, érték választásuk csak rájuk jellemző egyéni mintázata különbözteti meg öket másoktól. Lázasan keresett sokféleség mellett, tudat alatt mindig egy feltételezhető szimbiotikus egység felé vonzódtak. Cselekedeteik rugóiban egyfajta vezérlö, normatív eszmét kerestek és követtek, melyet a rendezettség képében véltek felfedezni. Céljaik és vágyaik a jövő felé fordították tekintetüket, olyasmire törekedtek, ami értékessé tette életüket. Kudarcaikból tanultak, bátran szembe néztek a kihívásokkal, mertek kockáztatni. Határhelyzetben mindig önmagukat választották, többnyire racionális döntéseket hoztak, jól sáfárkodtak képességeikkel és a kínálkozó lehetőségeikkel, ezért a kiteljesedett élet valóság lett számukra. A hétköznapok gondjai, bajai nem törték meg lelküket, több fény és kevesebb árnyék kísérte életüket. E többlet munícióval a tarsolyukban, erősebb hittel és bölcsebb életfilozófiával felvértezve tekintenek hátralévő életükre.

\section{Kudarcos életút ${ }^{17}$ /Ki vagyunk szolgáltatva a sors szeszélyének}

Születéskor a teremtőtől/természettől kapjuk létünk összes eredőjét, hogy az ismeretlen úton üdvük, vagy kárhozatunk legyen. A csalódott, kiábrándult, megkeseredett idős emberek, ha belenéznek lelkük zavaros tükrébe, tisztán látják, hogy életmüvük, tolla és ecsetje, remekmü helyett, csak szánalmas utánzatot produkált. Ha végig gondolják születéstől késő őszbe érő életük sok kínját, és néhány szép szivárványhídját, úgy érzik, nem lenne erejük még egyszer mindent, ugyanígy végig csinálni. A rossz szereposztás miatt, olyan volt az életük, mint egy örült játék, melybe véletlenül belecsöppentek, a játékszabályokat nem ők hozták, szinte semmiről sem dönthettek, legfeljebb elszenvedték a teremtő büntetését. Életük kezdetén felvett negatív kódok, olyan vakvágányokon indították el őket melyekről önerőből nem volt letérés, ki volt jelölve a tévút, ami ezután jött, csak reménytelen, sziszifuszi sziklagörgetés volt. Balga módon elhitték, hogy kedvük szerint szabad akaratukra bízva alakíthatják nekik tetsző önmagukat. Teljességre törekvő önmegvalósítási kísérleteik rendre kudarcot vallottak. Nem volt bennük kellő erő, kitartás, a helyes ösvényt szinte soha nem találták. Negatív énképük, labilis érzelmi töltésük - nyugtalanság, elvágyódás, szorongás - tudatalatti vágyaik elfojtott késztetéseiből eredtek. Visszatérő kríziseik maradandó nyomot hagytak törékeny lelkükben. Életük fordulópontjain, többnyire hibás döntéseket hoztak, rosszul mérték fel a kínálkozó lehetőségeket, ezért a jobb, a más, a kiteljesedett élet illúzió maradt számukra. Deficites életükért eleve elrendelt végzetüket kárhoztatják. „Ki vagyunk osztva, megvan helyzetünk, mit 
tehetnénk e szabály ellenében, mint álló csillagok az égen, változhatatlan rajzunk jellemünk",18 A csalódott emberek, életük alkonyán sem találják meg az integritást és elfogadó megértést, mely az élet végességébe való bölcs belenyugvást adja. Utolsó leheletükig lázadnak a sorsuk ellen, életenergiákat a tehetetlen düh, a harag és az elégedetlenség emészti fel. A halál árnyékában sem képesek aktívan törődni fogyó életükkel.

\section{Ambivalens (kétarcú) életút}

Janus arcú életutat bejárt emberek, ösztönösen elfogadják a létezés kettősségét: fény és árnyék, siker és kudarc, öröm és bánat egyaránt természetes velejárója az életnek. Nézetük szerint az élet jó-rossz döntések, véletlenek, hitek-tévhitek és vakhitek változata. Nem tudjuk, mi vár ránk, ezért fogadjuk el a sorsunkat olyannak amilyen. Egyszer fent, máskor lent. Jobbra, balra kileng életük ingája, egy idő után visszaáll a normális medrébe. Szélsőséges érzelmektől mentesen, racionalitással szemlélik a világot. „Hidegen nézz jóra, rosszra, hogy ha hív, ha biztat, állj meg, hullámzás a hullám sorsa, bármi csábít hajt elöre légy közömbös holtodiglan",19 Elmerülnek a mindennapokban, minimalizált céljaik hétköznapi szükségletek kielégítésre irányulnak. Félnek a csalódástól, ezért illúziók nélküli, óvatos középutat választják. Csak úgy megtörténnek velük a dolgok. Képtelenek túllépni, létük szükös határain, kerülik az élet nagy kihívásait, maximális biztonságra törekednek. Az önmegvalósítás magasabb szintje soha nem érintette meg lelküket. Vágyaikat, álmaikat a létezés alapszintjére kódolják. Úgy vélik, hogy a boldogság a szerencsés csillagzat alatt született emberek jussa, nekik az effajta földi jóból kevesebb jutott, de megelégedtek a kevesebbel is. Ha nagyritkán rájuk talált, e farkas léptü érzés, megbecsülték, mert tudat alatt érezték, hogy hamar elillan. Születéskor beléptek az ismeretlen életbe vezető ajtón úgy, hogy még nem volt semmi a birtokukban, életük végén kilépnek egy másik ajtón, úgy, hogy már nincs semmi a birtokukban. Azt kapták az élettől, amire kockázatkerülő lelküket ösztönösen kódolták: ambivalenciát. 


\section{Hogyan tegyük kiegyensúlyozottá magunkat időskorban?}

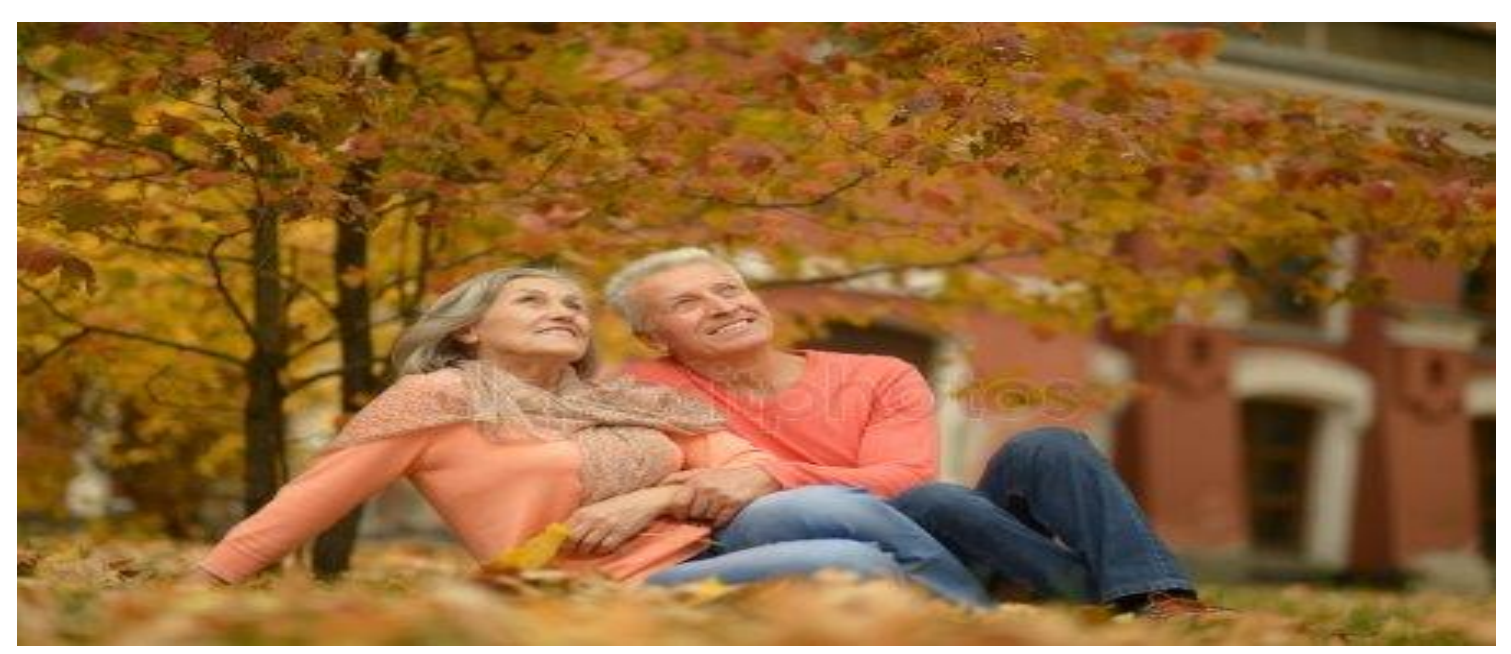

8. Ábra: Idős pár.https://hu.depositphotos.com/stock-photos/idős-emberek$\underline{\text { st100.html?qview }=6928848}$

\section{Létstratégiánk}

A halál árnyékában próbáljuk meg idegpályáinkban kódolt testi-lelki fájdalmainkat minimalizálni. Száműzzük agyunkból a rettegést, a félelmet a szorongást és az önostorozást.

Az öregkori bölcsesség feltételez egyfajta komplex intelligenciát, melynek főbb építőkövei:

- $\quad$ szellemi érettség (pozitív életfilozófia, hit, nyitottság, letisztultság,)

- mentális egyensúly (jó közérzet, optimizmus, derü, higgadtság, szélsőséges indulatoktól mentesség)

- aktív életmód (sport, hobby, közösségi kapcsolat, rendszeres elfoglaltság, megvalósítandó célok)

- elfogadás, elengedés, belenyugvás

Legyünk büszkék arra, hogy életünk törékeny csónakját szörnyü viharokon keresztül, öreg korunk csendes kikötőjébe navigáltuk. Ez a teljesítményünk akkor is figyelemre méltó, ha kudarcosnak ítéljük a mögöttünk hagyott utat. Bölcs belenyugvással fogadjuk el, hogy nem vagyunk korlátlan urai sorsunknak, a párkák fonalát nem mi szőjük és szakítjuk el. Botlásaink, tévedéseink ellenére, ez a mi utunk volt, mi mindent megtettünk, tőlünk ennyire telt. 


\section{Útravaló/Konklúziók}

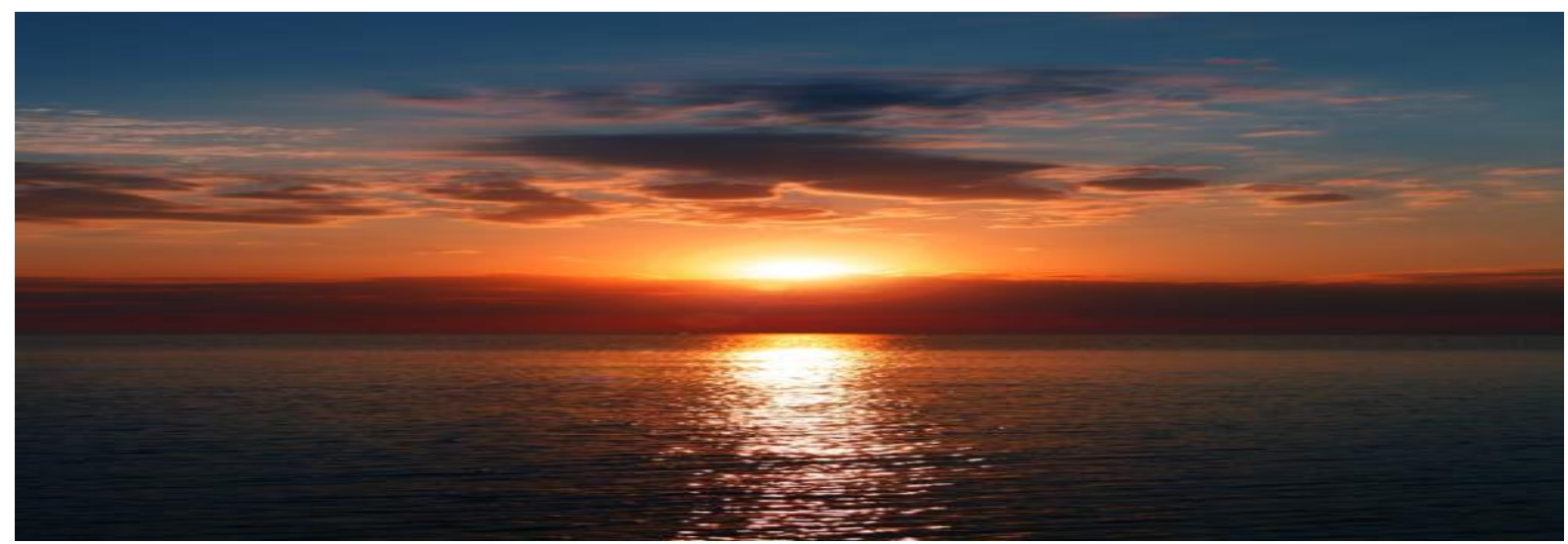

9. Ábra: Aranyóra /Alkonyat. https://www.pexels.com/hu-hu/foto/aranyora-eg-elso-ora-

felhok-1212600/

Fogadjuk el, hogy életvilágunk rideg otthona nem volt kompatibilis vágyainkkal, a szívünk belegyökerezett nehezen fékezhető ösztöneinkbe, ez okozta minden szenvedésünk. Engedjük el kielégületlen vágyaink, kísértő fantomjait, időskorban nincsen mód lelki térképünk újra rajzolására. Öreg fát nem lehet átültetni, tartja a népi bölcsesség. A mi dolgunk annyi volt az életben, hogy a ránk testált szerepet a lehető leghitelesebben eljátsszuk. Ha ez sikerült, ne legyen lelkiismeret furdalásunk. Gyötrelmes pillanat, amikor ráébredünk arra, hogy nincs már előttünk sok idő életünk gyertyái lassan csonkig égnek. Utolsó leheletünkig őrizzük lelkünkben a hitet, a reményt és a szeretetet ${ }^{20}$, e sarkalatos erények nélkül idős korunkban sem tudunk értelmesen élni. Legfőbb bíránk a lelkiismeretünk legyen, mert belső hangunk mondja meg, hogy mi a jó, és mi a rossz. A te világod te magad vagy. Tiéd a hatalom: lehetsz koldusa tenmagadnak, s király is magadon" "21 Életünk alkonyán tanuljunk meg bölcsen élni, hogy földi zarándoklatunk végén, a holdsugár ösvényen méltóképpen tudjunk az elíziumi mezőkre távozni. "Igen, igen. Meg kell öregedni. Egy pillanat még, valamit akartam... Mit is? Igen, élni. Tudom, most már késő. Mehetünk." 22

\section{$\underline{\text { Lektori Kommentár }}$}

A Magyar Gerontológia folyóirat közli Homor Tivadar Bölcs öregedés az életút alkonyán címü esszé-jellegü tanulmányát, amely széleskörü kitekintéssel foglalkozik az emberi élettel és annak öregedésbe forduló szakaszával. Mint emberismeretet, etikát tanító tanár mélyebb összefüggéseket is megfogalmaz. Minden valószínüség szerint saját személyes 
tapasztalatai, emberi kapcsolatai alapján teszi megállapításait, amelyek az öregedésről szóló szubjektív véleményét támasztják alá.

Ilyen dolgozat kiegészíti a tudományos elemzéseket. Helyesen mutatja be a sikeres, kudarcos és kétarcú életutat követő öregedés jellemzőit, a részleteiben sokarcú létformákat.

Nagyon fontos, hogy lássuk az életút szerepét az öregedés szociálpszichológiai minőségében (l. kohorsz- és konvoj-elméletek), ez a szerzőnél kiemelt jelentőséggel bír, a tanulmány fó érdeme. Azonban több helyen a szubjektív véleményét közli az egész élet, fôleg az idősödés folyamatát, dominálóan negatív jelenségekkel jellemzi, ami jellemző a megfogalmazásaira is. Ehhez bizonyára hozzájárul felmérésének eredménye (47\% kudarcos élet), amely valószínüleg egy sajátos csoport adatait tükrözi, tehát így kell értelmezni.

Mindezek alapján a nagyon szépen, intellektuálisan kidolgozott esszé az öregedés megítélésének, megélésének egyfajta, sok oldalt érintő, de a negatívumokat, bizonytalanságokat olykor kiemelö megközelítését képviseli, ami által viszont fontossá teszi minden idős számára az életút elemzését, az utolsó részben megfogalmazott életstratégiát: meg kell tanulni bölcsen élni.

\section{Irodalom}

1./ Áprily Lajos (2006): Összes költeményei. Osiris kiadó, Bp. ISBN: 9789633898857 https://bookline.hu/product/home.action?

(Letöltés: 2021.05.05.)

2./ Babits Mihály (2007): Összegyüjtött versei (Ladoameia) ) Osiris Kiadó, Bp., ISBN:9789633899588: $\quad$ https://www.libri.hu/konyv/babits_mihaly.babits-mihalyosszegyujtott-versei.html (Letöltés: 2021.05.05.)

3./ Babits Mihály (2007): Összegyüjtött versei.( Pszychoanalysis ) Osiris Kiadó, Bp., ISBN:9789633899588: $\quad$ https://www.libri.hu/konyv/babits_mihaly.babits-mihalyosszegyujtott-versei.html (Letöltés: 2021.05.05.)
4./
Digitális
szakadék
projekt.

https://www.nive.hu/index.php?option=com_content\&view=article\&id=641\#system-

message-container (Letöltés:2020.11.15) 
5./ Eminescu, Mihail (1974): Versei. (Ars Poetika) Európa Kiadó, Bp., https://www.antikvarium.hu/konyv/mihail-eminescu-mihai-eminescu-versei-3106

(Letöltés: 2021.05.06)

6./ Frost, Robert (2018): Versei. (Járatlan út) Európa Kiadó, Bp., ISBN:963-07-6319-2 https://www.antikvarium.hu/konyv/robert-frost-robert-frost-versei-46777

(Letöltés: 2021.05.06)

7./ Gilgames eposz: https://korok.webnode.hu/products/toth-tibor-a-gilgames-eposz/

(Letöltés:2020.11.17)

8./ Hádész. $\quad$ https://www.google.com/search?client=firefox-bd\&q=H\%C3\%A1d\%C3\%A9sz+vikip\%C3\%A9dia (Letöltés:2020.11.17)

9./ Harari, Yuval, Noah, (2017): Homo Deus. A holnap története. Bp. Animus kiadó. ISBN9789633244975

10./ Hársing László (1995): Bevezetés az etikába. Nemzeti Tk., Bp., (49-52)

11./ Homor Tivadar (1919): Holtpont (1-7.) http://mipszi.hu/cikk/130919-holtpont .

(Letöltés: 2021.05.06)

12./ Homor T.- Kamarás I. (2010): Emberismeret és etika. Apáczai K. Celldömölk, (75-76)

13./ József Attila (2014): Összes költeményei. (Osztás után) Digitalbooks.hu. kft. Bp., ISBN:9789639555069 https://www.libri.hu/konyv/jozsef_attila.jozsef-attila-osszes-versei-

$\underline{1 . h t m l}$ (Letöltés: 2021.05.06)

14./ József Attila (2014): Összes költeményei. (Reménytelenül) Digitalbooks.hu. kft. Bp., ISBN:9789639555069 https://www.libri.hu/konyv/jozsef_attila.jozsef-attila-osszes-versei1.html (Letöltés: 2021.05.06)

15./ Kháron, https://www.google.com/search?client=firefox-b-d\&q=Kharon+ladikja (Letöltés: 2021.05.06)

16./ Kundera, Milán (2018): A regény művészete. Európa Kiadó, ISBN: 9789634058939

17./ Losonczi Ágnes (2005): Bölcsebb vagy csak öregebb.[PDF]Pannon Szemle 13. 3, (43-57) losoncziagnes.hu > sites > default > files > pannon_szemle_oregsegrol (Letöltés: 2021.05.06) 
18./ Márai Sándor: A gyertyák csonkig égnek.(hangoskönyv) https://www.google.com/search?q=Márai+Sándor+a+gyertyák+csonkig+égnek\&client=fírefo $\underline{\mathrm{x}-\mathrm{b}}$ (Letöltés:2020.11.13)

19./ Mózes I könyve. Kiüzetés a paradicsomból. Átok.https://abibliamindenkie.hu/karoli/GEN/3/ (Letöltés: 2021.05.06)

20./ Rónay György: Versei. (A te világod) http://epa.oszk.hu/00300/00381/00140/alfoldy.ht (Letöltés: 2021.05.06)

21./ Szingularitás: Ray Kurzweil jóslata https://444.hu/2017/03/16/ray-kurzweil

(Letöltés: 20020. 11.05)

22./ Tamási Áron (2008): Ábel c. regénytrilógia. Ciceró Könyvstúdió Kft., Bp. ISBN: 9789635396207https://www.geniusz.hu/tamasi_aron-abel-trilogia (Letöltés: 2021.05.06)

\section{Képek}

1./Idős házaspár. elérés: /https://pixabay.com/hu/images/search/id\%C5\%91s\%20p\%C3\%A1 (Letöltés: 2020.12.15.)

2./ Michelangelo: Kiüzetés a paradicsomból. Részlet a szixtuszi kápolna mennyezet freskójából, elérés: /https://pixabay.com/hu/images/search/id\%C5\%91s\%20p\%C3\%A1r/https://hu.wikipedia.org/ wiki/Az_ember_buk\%C3\%A1sa (Letöltés:2021.05.02.)

3./Gilgames eposz-részlet. Ékírásos elérés: /https://upload.wikimedia.org/wikipedia/commons/b/bc/Library_of_Ashurbanipal_The_Flood _Tabl (Letöltés: 2021.05.02.)

4./1-4. Idős emberek arcai. elérés: https://hu.depositphotos.com/stock-photos/id\%C5\%91semberek-st200.html (Letöltés: 2021. 04. 10.)

https://pixabay.com/hu/photos/\%C3\%B6reg-ember-portr\%C3\%A9-utca- f\%C3\%A9rfi- 2/ https://pixabay.com/hu/images/search/id\%C5\%91seknek/?cat=people\&pagi=2 https://pixabay.com/hu/images/search/id\%C5\%91seknek/?cat=people\&pagi=2 
5./ Meditáció. elérés: /https://pixabay.com/hu/images/search/b\%C3\%B61csess\%C3\%A9g/ (Letöltés:2021. 05.03.)

6./ Gyászmunka elérés: /https://pixabay.com/hu/photos/emberi-f\%C3\%A9rfi-gy\%C3\%A1szszomor\%C3\%BAs\%C3\%A1g-2829510/ (Letöltés: 2021.05.07.)

7./ P. Gauguin: Honnan jövünk, kik vagyunk, hová megyünk? elérés: /https://moly.hu/enciklopedia/paul-gauguin-honnan-jovunk-kik-vagyunk-hova-megyunk (Letöltés: 2021.05.04.)

8./ Idős pár. elérés: https://hu.depositphotos.com/stock-photos/idős-emberekst100.html?qview=6928848 (Letöltés: 2021.05.04.)

9./ Aranyóra. elérés: /Alkonyat.https://www.pexels.com/hu-hu/foto/aranyora-eg-elso-orafelhok-1212600/ (Letöltés:2021.05.04)

\section{Jegyzetek}

1 József Attila: Reménytelenül c. költeményéből részlet. https://www.libri.hu/konyv/jozsef_attila.jozsef-attila-osszes-versei-1.html

${ }^{2}$ Babits Mihály: Laodameia c. költeményéböl részlet. Babits Mihály összegyüjtött versei https://mek.oszk.hu > html > vers0301

${ }^{3}$ Kháron: görög mitológiai alak, az alvilág révésze. A halottak lelkét ő viszi át ladikján a Sztüx folyón. https://www.google.com/search?client=firefox-b-d\&q=Kharon+ladikja

4 Hádész: az alvilág istene, a holtak ura a görög mitológiában. https://hu.wikipedia.org/wiki/Had\%C3\%A9sz

${ }^{5}$ Mózes I könyve. Kiűzetés a paradicsomból. Átok. https://abibliamindenkie.hu/karoli/GEN/3/ ${ }^{6}$ Gilgames: Sumér város, Uruk 5. királya, kr. e. 2650 körül uralkodott. Róla szól a Gilgames eposz, a mezopotámiai mitológia alapvető mủve, az emberiség legrégibb fennmaradt szépirodalmi alkotása. https://korok.webnode.hu/products/toth-tibor-a-gilgames-eposz/

${ }^{7}$ Yuval, Noah, Harari (2017): Homo Deus. A holnap története. Bp. Animus k. Részlet a könyv bevezetöjéből!

${ }^{8}$ Szingularitás: Ray Kurzweil jóslata szerint a 2030-as évek elején létrejön a szingularitás, vagyis a mesterséges intelligencia eléri, vagy meg is haladhatja az emberi intelligencia szintjét. E nézet szerint a számítógép olyan okos lesz, mint az ember, ha nem okosabb.... https://444.hu/2017/03/16/ray-kurzweil 
${ }^{9}$ Áprily Lajos (2009): Összes költeményei. Osiris kiadó, Bp. Részlet a költő öregségről szóló költeményéböl.

https://szfsze.webnode.hu/_files/200000195d9245da1d8/\%C3\%81prily\%20Lajos\%20\%C3\%

B6sszes\%20versei.pdf

${ }^{10}$ Losonczi Ágnes (2005): Öregségről szóló tanulmánya, részletesen elemzi az öregedés problémakörét .[PDF]Pannon Szemle 13. 3, 43-57. losoncziagnes.hu > sites > default > files > pannon_szemle_oregsegrol

${ }^{11}$ Digitális szakadék projekt. Magyarország Kormánya az Európai Unió támogatásával 22,9 milliárd forintra emelte a legalább 260000 fő digitális készségeinek fejlesztését célzó „Digitális szakadék csökkentése” címü kiemelt projekt keretösszegét. https://www.nive.hu/index.php?option=com_content\&view=article\&id=641\#system$\underline{\text { message-container }}$

12 Tamási Áron (2008): Ábel c. regénytrilógiájából idézet! Ciceró Könyvstúdió Kft., Bp. ISBN: 9789635396207https://www.geniusz.hu/tamasi_aron-abel-trilogia

${ }^{13}$ Milan, Kundera (2018): A regény müvészete c. könyvből részlet!. Európa Kiadó, ISBN: 9789634058939

${ }^{14}$ Robert Frost (2018): Járatlan út című verséből részlet. Európa Kiadó, Bp., ISBN:963-076319-2 https://www.antikvarium.hu/konyv/robert-frost-robert-frost-versei-4677

${ }^{15}$ Babits Mihály (2007): Összegyüjtött versei. Részlet a Pszychoanalysis c. versből! Osiris Kiadó, Bp., ISBN:9789633899588: https://www.libri.hu/konyv/babits_mihaly.babits-mihalyosszegyujtott-versei.html

${ }^{16}$ Hársing László (1995): Bevezetés az etikába. Nemzeti Tankönyvkiadó., Bp., (49-52) c. könyvében részletesen kifejti, hogy önmegvalósításunk és életutunk minőségét alapvetően befolyásolja erkölcsi értékrendszerünk (szándék, következmény, cselekvésmód).

${ }^{17}$ Homor Tivadar (1919): Holtpont (1-7.) http://mipszi.hu/cikk/130919-holtpont . Az írás a perszonális identitásfejlődés deficitjeit vizsgálja. Rávilágít arra, hogy a szociokulturális háttér, az önismeret, a genetikai kód, és a testi-lelki-szellemi diszpozícióink döntő mértékben befolyásolják életutunk minőségét.

${ }^{18}$ József Attila (2014): Összes költeményei. Digitalbooks.hu. kft. Bp., Idézet Osztás után c. költeményéböl. ISBN:9789639555069 https://www.libri.hu/konyv/jozsef_attila.jozsef-attilaosszes-versei-1.html 
${ }^{19}$ Mihail, Eminescu (1974): Versei. Európa Kiadó, Bp., Ars Poetica c. költeményéből idézet. https://www.antikvarium.hu/konyv/mihail-eminescu-mihai-eminescu-versei-3106

${ }^{20}$ Homor T.- Kamarás I. (2010): Emberismeret és etika. Aáczai Kiadó. Celldömölk (75-76) A sarkalatos erények betartásával alkalmassá tesszük szívünket belső hangunk (lelkiismeretünk) meghallására.

21 Rónay György: A te világod c. költeményböl részlet http://epa.oszk.hu/00300/00381/00140/alfoldy.ht

22 Márai Sándor: A gyertyák csonkig égnek. c. hangoskönyvből részlet https://www.google.com/search?q=Márai+Sándor+a+gyertyák+csonkig+égnek\&client=firefo $\underline{x-b}$

\section{A szerző:}

\section{Homor Tivadar}

pedagógia, történelem, emberismeret-etika szakos tanár 9029.Győr, Szabadság u. 48/B

tel: $30 / 337-6678$

homtiv@freemail.hu 